\title{
CONDITIONS OF FISH FARMING IN NATURA 2000 AREAS, BASED ON THE EXAMPLE OF THE CATCHMENT OF BARYCZ
}

\author{
Katarzyna Tokarczyk-Dorociak', Andrzej Drabiński', Szymon Szewrański², \\ Sławomir Mazurek ${ }^{3}$, Wanda Kraśniewska ${ }^{3}$ \\ 1 Institute of Landscape Architecture, Wrocław Universiy of Environmental and Life Sciences, pl. Grunwaldzki \\ 24a, 50-363 Wrocław, Poland, e-mail: katarzyna.tokarczyk-dorociak@up.wroc.pl \\ 2 Department of Spatial Economy, Wroclaw University of Environmental and Life Sciences, Grunwaldzka 53, \\ 50-357 Wrocław, Poland \\ 3 Stawy Milickie SA, Ruda Sułowska 20, 56-300 Milicz, Poland
}

Received: 2016.03.31 Accepted: 2016.06.01 Published: 2016.07.01

\begin{abstract}
One of the factors that contributed to the construction of approx. $77 \mathrm{~km}^{2}$ offish ponds in the catchment of Barycz starting from the $13^{\text {th }}$ century, which in turn transformed the woods into a mosaic of waters, forests and arable land, were the advantageous physiographic conditions. Fish farming operations conducted in this area led to the creation of a cultural landscape characterised by unique natural values, similar to the natural landscape. Approx. 240 species of birds are observed here, of which 170 are nesting species. Due to its natural values, this area has been subject to natural reserve protection as part of the Landscape Park "Dolina Baryczy" (the Barycz Valley). It was entered in the "Living Lakes" list and it is protected under the Ramsar Convention as well as under the European nature protection network Natura 2000. The established forms of nature protection mean the introduction of a certain binding regime, pursuant to which the economic activity conducted in protected areas must take into account the prohibitions and orders introduced by documents that establish the said forms of protection. Additionally, there is a legal requirement to create a protection plan or conservation plan that constitutes a basis for the realisation of conservation-related objectives. A commercial company Stawy Milickie S.A. (public limited company) operates in the area of this largest fish pond complex in Poland. The scope of its operations includes more than just the breeding and sale of freshwater fish (6500 ha of ponds) but also environmental protection, environmental education and the development of tourism as well as stimulating the development and professional activation of local communities basing on the natural resources that exist in the catchment of Barycz.This study presents the conditions related to fish farming operations conducted in this area. Conducting an extensive management (i.e. often uneconomical from the economic point of view) is a prerequisite for maintaining the biodiversity of this naturally valuable area. The conservation plan of the nature reserve "Stawy Milickie" (Milicz Ponds) contains a series of obligations and limitations with respect to fish farming. The development strategy of the Stawy Milickie SA Company takes into account all these conditions.
\end{abstract}

Keywords: carp ponds, Barycz Valley, Natura 2000, fish farming

\section{INTRODUCTION}

Since the $13^{\text {th }}$ century, fish farming operations conducted in the Milicz Ponds have contributed to the creation, and later also to the protection of a wide range of semi-natu- ral habitats and water-dependent landscapes characterised by a high natural diversity. The main function of fish ponds is the production of food, although their role in water retention and the protection of water quality as well as in maintaining biodiversity has been attracting 
increasing attention recently [Walczuk, Romanowski, 2013]. Fish ponds are a very important habitat of wetland birds, and they are quite often one of the most important ecosystems in the aspect of biodiversity in a landscape transformed by humans.

The example of Milicz Ponds shows that anthropogenic activity may foster the creation of a landscape characterised by high natural and landscaping values. Thus, in this instance, humans have contributed to the "production of nature". Due to the above it is necessary to conduct fish farming operations in such way that will enable the protection of these values. This may be the time when the highest number of conflicts occurs, as, on the one hand, production in fish farming ponds fosters the cocreation of landscape values, but, on the other hand, many operations related to fish farming and production have a negative influence on the same values. In the Barycz Valley, the coexistence of fish farming and environmental protection is practically an absolute precondition for the protection of the natural values characterised by a high level of biodiversity and landscape diversity.

\section{CHARACTERISTICS OF THE TEST AREA}

Barycz is a right-side tributary of the Odra River, of a length of $136 \mathrm{~km}$. The catchment area is $5547 \mathrm{~km}^{2}$. The Barycz River has its source in the marshy Milicz Basin, and its estuary in the vicinity of Wyszanów (Figures 1 and 2). The Barycz river network has been subject to significant changes during the years. These changes resulted mainly from the economic usage of the catchment, in particular in connection with the fish farming operations that have been conducted here since the $13^{\text {th }}$ century. Factors that fostered the development of fish farming included the natural terrain formation, low inclinations of the Barycz river, the presence of flatlands and water availability. Since the beginning of the fishing operations of the Cistercian monastery, the fish farming operations have been the main factor that shaped the Barycz Valley. The currently observed natural and landscaping diversity of the discussed area results from the transformation of the Barycz catchment by fish-farming operations. The catchment has been subject to various forms of conservation for over half a century. The following environmental protection forms were established

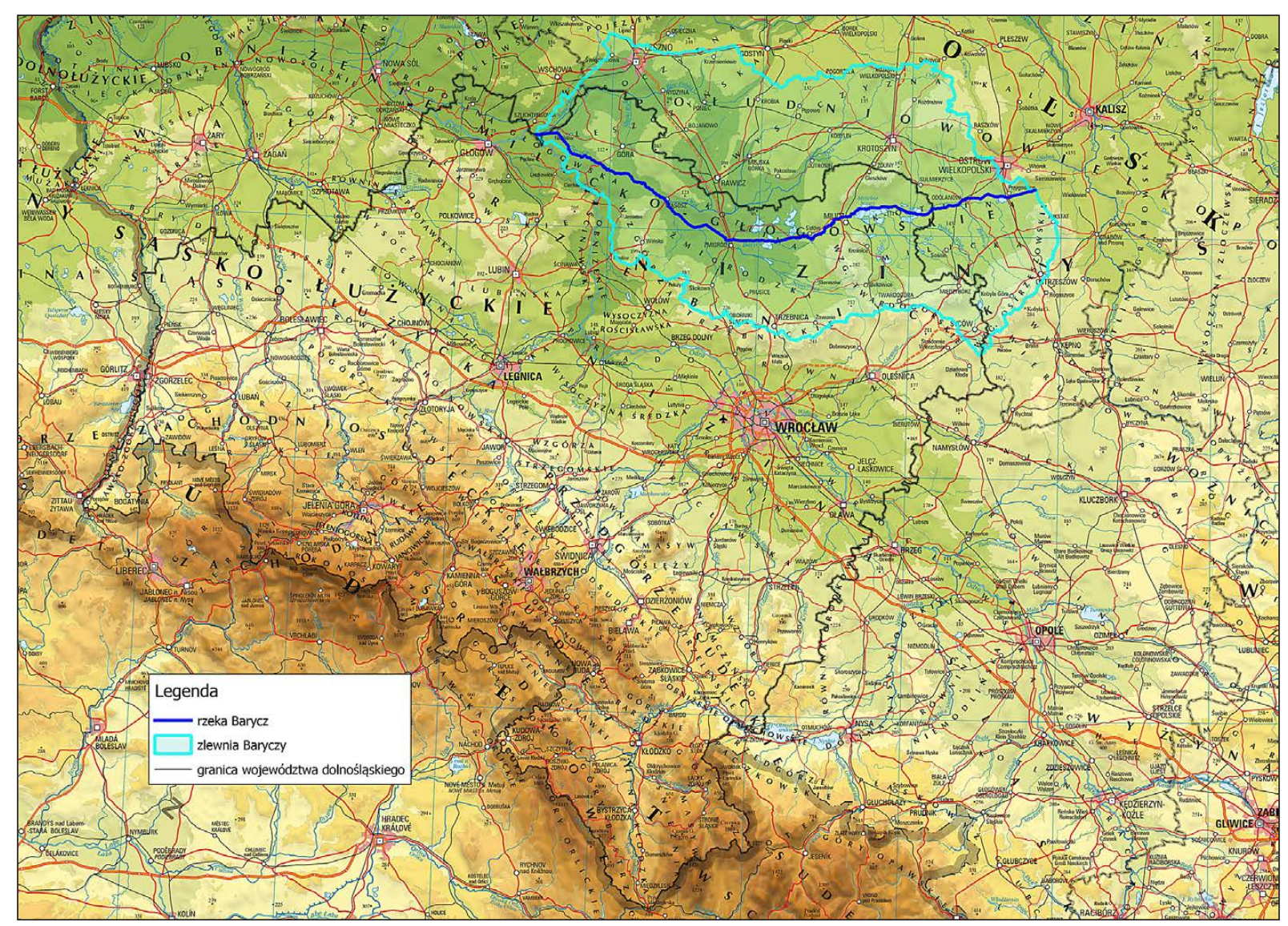

Figure 1. Location of the Barycz catchment 
here: Landscape Park Dolina Baryczy (Barycz Valley), Protected Landscape Area Dolina Baryczy (Barycz Valley), nature reserves and Natura 2000 protection areas: SPA PLB020001 Dolina Baryczy (Barycz Valley) and PLH020041 Ostoja nad Baryczą (Barycz Refuge).

\section{Fish farming}

Fish farming in this area started to develop as early as at the beginning of the $13^{\text {th }}$ century. Natural terrain formation, low inclinations of the Barycz River and the presence of flatlands facilitated the construction of ponds. In the Middle Ages, the Cistercian monastery created approx. 2300 ha of ponds. In the $16^{\text {th }}$ century, several hundred hectares of new ponds were constructed by the Kurzbach family, and later a fish farming boom took place in the $17^{\text {th }}$ and $18^{\text {th }}$ centuries. During this period, the area of ponds increased from 9970 ha (in 1739) to 13195 ha (in 1783) and then gradually decreased to 6300 ha (at the turn of the $19^{\text {th }}$ and $20^{\text {th }}$ century) [DUŚ, 2009]. Nowadays, the Stawy Milickie SA Company is operating an area of approx. 7000 ha. The natural and landscaping values of the Barycz Valley are mainly connected with the functioning of the fishing ponds, traditionally called the Milicz Ponds. It is a complex of carp ponds located in the vicinity of Milicz, Stawno, Ruda Milicka and Ruda Sułowska. The protection of natural values depends on the continuity of the conducted fish farming operations. Currently, the entity responsible for the operation of Milicz Ponds is the Stawy Milickie SA Company. It was created pursuant to a tri-lateral agreement between the Agricultural Property Agency, the Lower Silesian Voivodeship and the Voivode of Lower Silesia on the establishment of a public limited company from the dissolved National State Budget Facility Stawy Milickie. In November 2010, the Lower Silesian Voivodeship established the public limited company Stawy Milickie SA, with its registered seat in Ruda Sułowska. On October $11^{\text {th }}$, 2011, the Minister of State Treasury signed a decision on free assignment of a package of shares worth PLN 135.8 million to the Lower Silesian Voivodeship. As a result, the Voivodeship became the sole holder of $100 \%$ shares in the company. The main development directions are farming and sales of freshwater fish, mainly the traditional regional product: the Milicz carp. Currently, the average annual commercial production of carp fluctuates between 1500-1800 tonnes. It is planned to achieve a farming fish production of 3000 tonnes of various species. The whole breeding cycle of the Milicz carp takes place in the Barycz Valley (including carp fry, which is also bred in the Milicz Ponds). The production cycle of the Milicz carp lasts 3 years and consists of 5 stages: spawning, breeding carp fry, growing and wintering of autumn fry, table fish farming, catches.

Fish feed on natural nutrients generated in the ponds, and are additionally fed with only cereal fodder. Production is based on breeding methods traditionally used in the region. Like centuries ago, most of the works are performed manually by qualified fishermen under veterinary supervision, in compliance with the requirements of humanitarian treatment of fish.

\section{NATURAL VALUES AND ENVIRONMENTAL PROTECTION FORMS IN THE BARYCZ VALLEY}

Centuries of fish farming operations conducted in the Barycz Valley led to the creation of a unique landscape. Due to landscape and natural diversity these values have been covered by various forms of nature protection. The Milicz Ponds (Figure 2) are particularly valuable from the natural and landscaping point of view. This is a cultural landscape, as it emerged as a result of combined environmental and cultural conditions that generated a unique structure which manifests itself in a form of regional identity, perceived as a specific physiognomy [Myga-Piątek, 2006]. The landscape of the Milicz Ponds was created by anthropogenic transformations of the natural landscape, where hydrological structures were constructed for the purposes of fish farming.

Currently, the Stawy Milickie SA Company is operating an area of approx. 7000 ha of ponds, of which $65 \%$ are covered by protection as natural reserve. The largest ornithological reserve in Poland "Stawy Milickie" (Milicz Ponds), of an area of 5324.31 ha was created here. (Approx. 240 species of birds are observed here, of which 170 are nesting species). About $97.5 \%$ of the area of the Milicz Ponds is protected under the European environmental protection network Natura 2000. Several nature protection areas were created in the catchment of Barycz, including the spa "Dolina Baryczy" (Barycz Valley) (55517 ha) and the SAC "Ostoja nad Baryczą" (Barycz Refuge) (82026 ha), which is nearly identical with the land- 


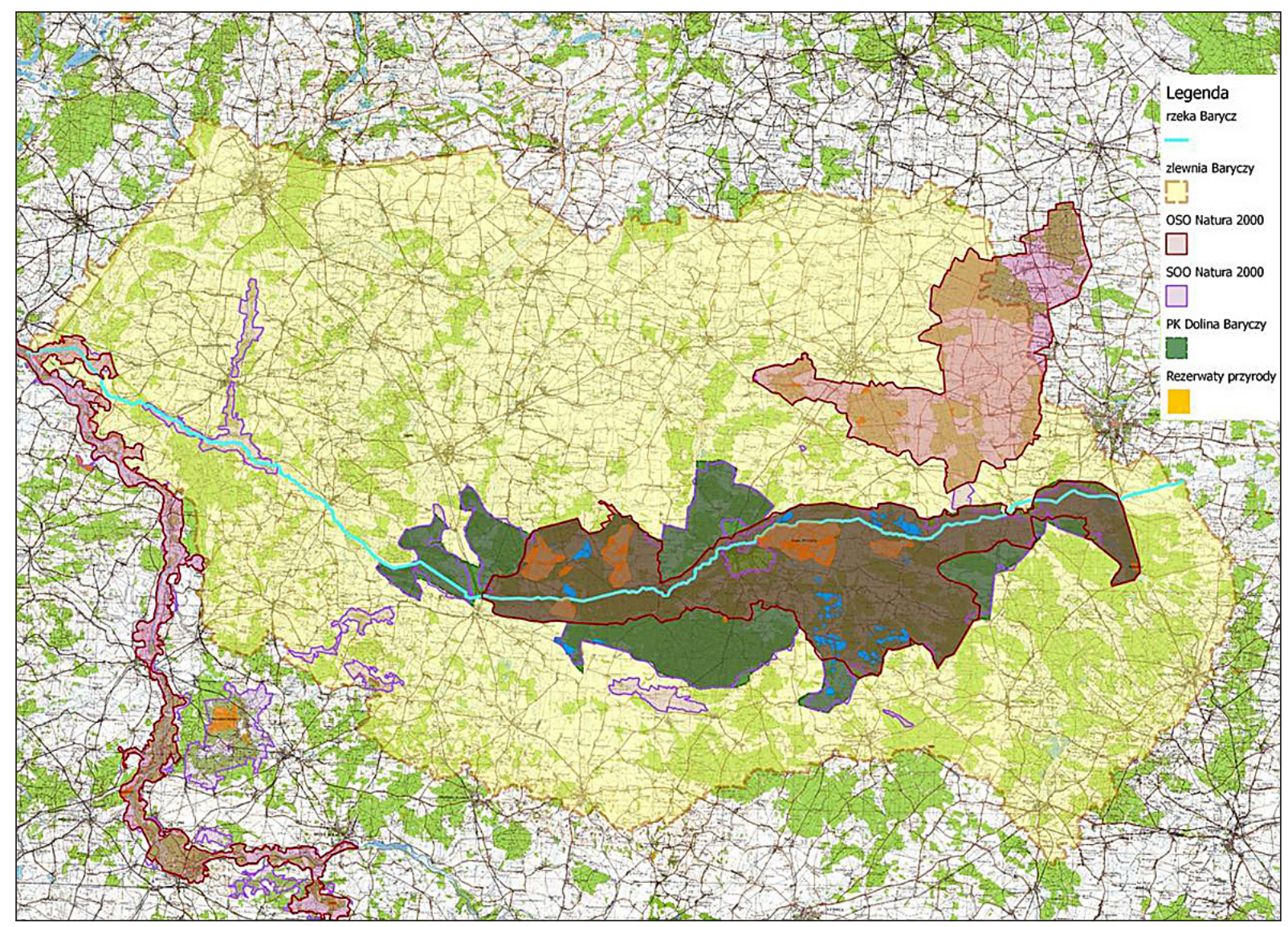

Figure 2. Location of the Milicz Ponds complex in the catchment of the Barycz Valley and nature protection areas (own study based on data from the Regional Director for Environmental Protection).

scape park "Dolina Baryczy” (Barycz Valley). It consists of a mosaic of fish ponds, flood meadows and wetlands, arable land and forests, crossed by water courses with numerous fragments of riparian forest and alder swamp forests. The refuge is essential for the biodiversity of the lowland part of south-western Poland. 14 types of protected habitats specified in Appendix I to the Habitats Directive and 14 species listed in Appendix II thereto were found here. In 1995 these areas were included in the list of areas protected under the Ramsar Convention, and they were the only area in Poland that was covered by the worldwide water bodies protection programme "Living Lakes".

The established forms of nature protection mean the introduction of certain binding regimes, pursuant to which the economic activity conducted in protected areas must take into account the prohibitions and orders introduced by documents that establish the said forms of protection. Pursuant to the Act on Environmental Protection and to the habitat and birds directives, any operations conducted in Natura 2000 areas must not have a negative influence with respect to the protection objectives established for the given area.

\section{FISH FARMING AND ENVIRONMENTAL PROTECTION}

Since the beginning, fish farming in ponds located in the Barycz Valley has been based on natural, extensive methods. This was largely connected with the physiographic conditions - the ponds were large and the land fertile, so natural nutrition was sufficient to maintain the desired production levels. Later on, low level of investments in the development of state-owned facilities prevented the intensification of fish farming in the ecosystem of ponds. Fishermen conducted their farming operations basing on the knowledge of natural processes and using the natural potential. Such methods resulted in the fact that the objectives related to the protection of the Milicz Ponds ecosystem became equally important as fish production.

Currently, the operations of Stawy Milickie SA (Public Limited) Company cover the following areas: breeding and sales of freshwater fish, promoting Lower Silesia and the Barycz Valley, protection of the ecosystem of the "Stawy Milickie" (Milicz Ponds) natural reserve and of 
other ponds managed by the Company, in compliance with the locally binding environmental protection forms, promoting the natural environment and landscape and development of tourism in the region of the Barycz Valley, co-operation with national and foreign environmental education centres and environmental protection organisations, creating and participating in the creation of local and regional development programmes. Similar objectives were realised by the State Budget Facility Stawy Milickie (operating since January 2000), including: maintaining the integrity of the ecosystem of the Barycz Valley, conducting fish farming operations, realisation of investments and renovations of the ponds, conducting editorial and educational operations, organisation of leisure and recreational activities as well as promoting tourism and regional production.

The statutes of the Company stipulate clearly that its goal is to achieve sustainable development of the Milicz Ponds, which means that it is necessary to take into account all conditions resulting from the environmental protection needs while conducting fish farming operations. The question arises, whether this is possible at all? What are the challenges faced by fishermen and by natural scientists? In this case, consensual solutions will be dictated by knowledge, the results of conducted research and dialogue-oriented attitude of both parties. Without mutual understanding it will be impossible to maintain the unique ecosystem of the Milicz Ponds.

Carp ponds are essential for environmental protection. Obviously, the most important aspect is the creation of valuable habitats and maintaining the unique natural values generated by human activity. Maintaining the carp ponds is important for the protection of biodiversity resources on a European scale. They also have a positive influence on the micro-climate and water retention.

Extensive fish farming (fostering environmental protection) allows for manufacturing high-quality products while offering the region an opportunity to thrive based on the generated values. In order to maintain the natural values generated as a result of co-operation between the fishermen and nature it is necessary to recognize the existing threats and then to avoid them.

The main threats for natural values resulting from fish farming operations include:

- disturbing water relations,

- elimination or intensification of fish farming,
- overgrowing of ponds as a result of the succession of rushes and sedges (following the discontinuation of fish farming operations),

- invasive plant and animal species,

- regulation of water courses without respecting the requirements related to the protection of habitats and individual species,

- contamination of waters in the catchment of Barycz.

Some other significant threats linked to other human activities in the catchment of Barycz are connected with:

- the construction of artificial dam reservoirs, particularly in the upper part of the catchment,

- the intensification of tourist traffic,

- the construction of residential and recreational development in the proximity of ponds,

- summer droughts that lead to water deficits in the ponds.

At the same time, in order to protect the natural values in carp ponds it is necessary to perform a series of operations with the aim to maintain or improve biodiversity. Sometimes they are also important due to economic reasons, but often they should be performed only in order to realise the goals related to natural protection, e.g.: introducing only native species (this applies to breeding fish and plants), regular mowing of reed (taking into account the proper cutting season and the proportion between open and overgrown water surface), scheduling dates of re-filling the ponds with water considering the vegetation of the species that inhabit the pond [Völkl, 2007].

A situation might occur, particularly with respect to fish farming, when the owners will be legally obliged to continue the operations aimed at the protection of a Natura 2000 area, due to the fact that the discontinuation of fish farming (liquidation of ponds) would have a negative influence on such protected area. It might happen that the owners of a pond included in the Natura 2000 network will be bound to maintain water in the pond. Otherwise (pursuant to Art.127 of the Environmental Protection Act) they will be punished by arrest, fine, or up to two years of imprisonment due to significant reduction of value. In practice, this means that pond owners have to invest their own means in the protection of public interest [Radecki, 2010]. This is why it is so important to take actions that improve the costefficiency of fish farming operations in protected areas. Fish farming that is both cost-efficient and 
correct from the point of view of environmental protection will provide the best conditions for the realisation of guidelines resulting from the natural protection forms that exist in the ponds.

\section{ENVIRONMENTAL PROTECTION GUIDELINES IN THE "MILICZ PONDS" REGION}

It is obligatory to create a protection plan for natural reserves, landscape parks or Natura 2000 areas, or a conservation plan (for Natura 2000 areas only).Currently only the "Stawy Milickie" (Milicz Ponds) nature reserve is covered by an approved protection plan. Conservation plans for Natura 2000 areas are being developed. There is no conservation plan and no works are in progress regarding such plan for the Landscape Park "Dolina Baryczy” (Barycz Valley).

All forms of environmental protection applied in the Barycz Valley are subject to the prohibitions and obligations introduced by the Act of April 16 2004 on Environmental Protection (Journal of Laws of 2013, item627 incl. further amendments).

The most restrictive form of environmental protection introduced in this area is a nature reserve.The major part of the carp ponds in the catchment of Barycz is subject to protection as part of the newly established ornithological reserve "Milicz Ponds". The main objective of the reserve is to protect numerous particularly valuable and rare species of birds and parts of wetland and marsh habitats where these birds nest, prey and rest, as well as to protect other species of plants, animals and their habitats that occur in the reserve.

The identification of potential and existing threats along with ways to counteract them, prohibitions, orders and recommendations related to the realisation of the conservation objectives of the reserve are contained in Regulation 28 of the Regional Director for Environmental Protection in Wroclaw of December 20, 2013, on the creation of a conservation plan for the natural reserve "Stawy Milickie" (Milicz Ponds).

The conservation plan also introduced certain provisions to the spatial development conditions and directions study of the municipality and the local spatial development plans for the municipalities Milicz and Żmigród, as well as to the spatial development plan for the Lower Silesian Voivodeship. These provisions concern the elimination or minimisation of external threats. The protection plan for the reserve (as well as the conservation plan for the Natura 2000 area) is a local legislation act and its provisions are prevailing with respect to newly created planning instruments.

The Protection Plan of the reserve clearly specifies the role of fish farming in the maintaining of the natural values of the reserve. The conditions that are essential for the realisation of the objectives of the reserve include:

- The presence of an entity conducting fish farming operations within the borders of the reserve, which is one of the largest employers in the Milicz and Żmigród municipalities.

- maintaining and conducting fish farming operations without violating the diversity of habitats and species in the ponds,

- maintaining the necessary amount of water of appropriate quality for the ponds located in the catchment of Barycz,

- maintaining the natural environment for wetland birds and other species connected with water, grassland and forest habitats,

- maintaining wildlife corridors and feeding areas for birds, in particular the main ecological corridor - the Barycz Valley that connects all five pond complexes [Regulation No. 28].

The protection plan introduced active landscape protection by providing a list of protective actions with respect to specific zones, along with the principles for conducting manufacturing and commercial activities, including agriculture.

Sample protective actions in the active protection area are as follows [Regulation No. 28]:

- Maintaining traditional, regular fish farming in the ponds that is necessary to maintain and protect the habitats and species of pond ecosystems on a level that does not pose a threat for the quality of the natural environment.

- Performing the necessary works related to fish farming in compliance with good fishing practices and with use of traditional production methods that support the protection and improvement of the environmental conditions and allow to maintain biodiversity.

- Maintenance and repair works should be conducted outside the birds' breeding season. As far as water courses are concerned, works should be performed only on one bank.

- In ponds scheduled for repairs, bottom fragments should be shaped in form of shallow sandbars (shoals) gradually inclined towards the water level. 
- Maintaining or creating a gentle formation of shores, islands, piles and shallows (inclination should not exceed $30^{\circ}$ ). In ponds scheduled for repairs, whenever possible, bottom fragments should be shaped in a gradually inclined form (tasks aimed at the protection of alluvial species).

- In order to maintain the feeding areas of the greylag goose(Anser anser) with their young, it is recommended to mow (at least once a year, in the vegetation season) in all of the complexes of dykes (crowns and slopes).

- Limitation of the population of alien species; for brown bullhead (Ameiurus nebulosus) and topmouth gudgeon (Pseudorasbora parva)careful elimination of all specimen obtained during yield, for the grass carp (Ctenopharyngodon idella) - limitation of the population of grass carp bred.

- Ponds of the highest ornithological values (including:Jeleni Pond I,II,III , the Ponds Stary, Mewi Duży, Grabownica, Słoneczny Górny, Andrzej, Leszek, Jan, Uroczy, Kaczy) should be completely filled by the end of February, taking into account the hydrological conditions in the given year and depending on the fish production cycle in the given pond.

- In order to limit the conflicts caused by losses connected with birds feeding (eating fish and fodder), the dispersion of cormorants and controlled reduction of their nests are permitted. The Plan contains a detailed specification of the principles and schedules for destroying nests. It also stipulates that a breeding colony consisting of a minimum of 15 nests should remain in each of the ponds.

\section{NEW INVESTMENTS AND PLANNED ACTIONS}

Thanks to the operations of the Stawy Milickie SA Company, as well as to the activities of NGOs that have been active in the area for several decades, the Barycz Valley and the Milicz Ponds have become a renowned regional brand. The Local Action Group "Dolina Baryczy" is actively operating here with the aim to support the sustainable development of the area. Another organisation is the newly established Local Product Cluster of the Barycz Valley and the Trzebnickie Hills, which is developing a promotional strategy for food products manufactured in the region.
The Stawy Milickie SA Company is dynamically developing its tourist offer by constructing the NATURUM hotel and restaurant and the $\mathrm{Mu}-$ seum of Tradition and Fishing. Numerous tourist routes are being created (for hiking, biking, canoeing and horse-riding) and tourist infrastructure (boarding houses, restaurants, agrotouristic farms) is developing.

The Stawy Milickie SA Company has recently initiated the procedure of applying for entering the Milicz Ponds into the UNESCO world heritage list.Centuries of cultural heritage and unique natural value of the area make the area a perfect candidate for qualification in the mixed sites category. What is important is the fact that the Milicz Ponds are a perfect example of successful co-operation between economic activity (fish farming) and environmental protection, which is largely connected with conducting extensive fish-farming operations that foster maintaining biodiversity. Both the state of natural and cultural values and the processes of co-existence of humans and nature based on sustainable development of the area deserve to be protected.

\section{SUMM,ARY AND CONCLUSIONS}

With a proper approach to fish farming, considering all benefits obtained from the conducted operations, one may claim that it is one of the more cost-effective areas of human activity. It co-creates nature, contributes to the creation of a cultural and natural landscape, leads to the production of high quality food and provides employment. Professor Wróbel [1994] noted that "the economic, natural and cultural functions of the ponds are an argument for maintaining them and even increasing their area". Fish ponds are a classic example of a situation where economics meets nature. It is worth noting that without fish-farming operations, the ponds would cease to exist, along with valuable habitats of flora and fauna. Thus, we should strive to achieve a situation where satisfactory profits (obtained not only from the sales of fish, but also from making some facilities available to tourists and from water and environment protection programmes) are obtained without affecting the stability of the ecosystem.

In order to enable the co-existence of valuable natural areas and a cost-effective fish farming economy, it is necessary to: 
- take into account all requirements related to environmental protection on facilities used for fishing,

- prevent the privatisation and dispersion of ownership,

- differentiate income sources of farms in order to maximise profits,

- introduce economic and financial mechanisms that would take into account the non-financial benefits that the society obtains from maintaining extensive fish-farming operations in the catchment of Barycz, in particular by increasing the pricing of ecosystem-related services connected with fish ponds.

The example of economic activity conducted in the Barycz Valley shows that people not only exploit natural resources but can also create them if a roper approach is maintained.

\section{REFERENCES}

1. Duś J. 2009. Stawy Milickie - historia i stan obecny (The Milicz Ponds - history and current state), in: Kurkowski M., Drabiński A.: Ochrona przyrody w Parku Krajobrazowym „Dolina Baryczy”.Stan obecny - zagrożenia - perspektywy. (Nature protection in the Landscape Park "Dolina Baryczy". Currentstate - threats - perspectives. Wroclaw University of Environmental and Life Sciences), pp. 2-26.

2. Radecki W. 2010. Likwidacja stawów objętych ochroną przyrody jako obszar specjalnej ochrony ptaków Natura 2000 (Liquidation of ponds covered by nature protection as special protection area of birds) Ochrona Środowiska. Prawo i Polityka, No. 3, 53-54.

3. Völkl W. 2007. Die Bedeutung und Bewertung von bewirtschaftetenTeichenfür den Naturschutzeinschlisslich des Fischartenschutzes. Znaczenie i ocena stawów produkcyjnych dla ochrony przyrody, z uwzględnieniem ochrony gatunków ryb (The meaning and evaluation of fish farming ponds for natureprotection, including fish species protection) Publisher: Oberfranken, Bezirk Franken. Fachberatung für Fischerei.

4. Walczuk T., Romanowski J. 2013. Przyrodnicze i ekonomiczne uwarunkowania gospodarki stawowej w rezerwacie ornitologicznym „Stawy Raszyńskie" (Natural and economic conditions of fish farming in the ornithological reserve ,Stawy Raszynskie"). Woda - Środowisko - Obszary Wiejskie. T. 13. Z. 4(44), 175-184.

5. Wróbel S. 1994. Stawy i ryby. (Ponds and fish), Aura 6, p. 18-19.

6. Zarządzenie nr 28 Regionalnego Dyrektora Ochrony Środowiska we Wrocławiu z dnia 20 grudnia 2013 r. w sprawie ustanowienia planu ochrony dla rezerwatu przyrody "Stawy Milickie" (Regulation 28 of the Regional Director for Environmental Protection in Wroclaw of December 20, 2013, on the creation of a conservation plan for the natural reserve "Stawy Milickie") (Official Journal Of The Lower Silesian Voivodeship, ITEM 6632, Wrocław. 